\section{ECOHSTOR}

Make Your Publications Visible.

\section{A Service of}

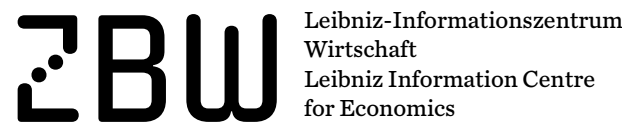

Akarca, Ali T.; Tansel, Aysit

\title{
Working Paper \\ Social and economic determinants of Turkish voter choice in the 1995 parliamentary election
}

IZA Discussion Papers, No. 2881

Provided in Cooperation with:

IZA - Institute of Labor Economics

Suggested Citation: Akarca, Ali T.; Tansel, Aysit (2007) : Social and economic determinants of Turkish voter choice in the 1995 parliamentary election, IZA Discussion Papers, No. 2881, Institute for the Study of Labor (IZA), Bonn

This Version is available at:

http://hdl.handle.net/10419/34418

Standard-Nutzungsbedingungen:

Die Dokumente auf EconStor dürfen zu eigenen wissenschaftlichen Zwecken und zum Privatgebrauch gespeichert und kopiert werden.

Sie dürfen die Dokumente nicht für öffentliche oder kommerzielle Zwecke vervielfältigen, öffentlich ausstellen, öffentlich zugänglich machen, vertreiben oder anderweitig nutzen.

Sofern die Verfasser die Dokumente unter Open-Content-Lizenzen (insbesondere CC-Lizenzen) zur Verfügung gestellt haben sollten, gelten abweichend von diesen Nutzungsbedingungen die in der dort genannten Lizenz gewährten Nutzungsrechte.
Terms of use:

Documents in EconStor may be saved and copied for your personal and scholarly purposes.

You are not to copy documents for public or commercial purposes, to exhibit the documents publicly, to make them publicly available on the internet, or to distribute or otherwise use the documents in public.

If the documents have been made available under an Open Content Licence (especially Creative Commons Licences), you may exercise further usage rights as specified in the indicated licence. 


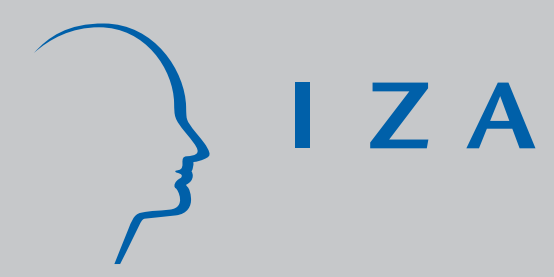

IZADP No. 2881

Social and Economic Determinants of Turkish Voter Choice in the 1995 Parliamentary Election

Ali T. Akarca

Aysit Tansel

J une 2007 


\title{
Social and Economic Determinants of Turkish Voter Choice in the 1995 Parliamentary Election
}

\author{
Ali T. Akarca \\ University of Illinois at Chicago \\ Aysit Tansel \\ Middle East Technical University \\ and IZA \\ Discussion Paper No. 2881 \\ June 2007 \\ IZA \\ P.O. Box 7240 \\ 53072 Bonn \\ Germany \\ Phone: +49-228-3894-0 \\ Fax: +49-228-3894-180 \\ E-mail: iza@iza.org
}

\begin{abstract}
Any opinions expressed here are those of the author(s) and not those of the institute. Research disseminated by IZA may include views on policy, but the institute itself takes no institutional policy positions.

The Institute for the Study of Labor (IZA) in Bonn is a local and virtual international research center and a place of communication between science, politics and business. IZA is an independent nonprofit company supported by Deutsche Post World Net. The center is associated with the University of Bonn and offers a stimulating research environment through its research networks, research support, and visitors and doctoral programs. IZA engages in (i) original and internationally competitive research in all fields of labor economics, (ii) development of policy concepts, and (iii) dissemination of research results and concepts to the interested public.
\end{abstract}

IZA Discussion Papers often represent preliminary work and are circulated to encourage discussion. Citation of such a paper should account for its provisional character. A revised version may be available directly from the author. 


\section{ABSTRACT \\ Social and Economic Determinants of Turkish Voter Choice in the 1995 Parliamentary Election ${ }^{*}$}

1995 Turkish parliamentary election was held almost under the conditions of a controlled experiment. The unique cross-section data pertaining to this election is utilized to study the voter behavior in Turkey. Turkish voters are found to take government's economic performance into account but not look back beyond one year. A poor performance is found to benefit the extremist opposition parties at the expense of the major incumbent party. The minor incumbent and the centrist opposition parties appear to be unaffected by economic conditions. Voters also exhibit a tendency to vote against the parties holding power. The party preferences of Turkish voters depend on their socioeconomic characteristics as well.

JEL Classification: D72

Keywords: elections, voter behavior, economic voting, party preference, Turkey

Corresponding author:

Ali T. Akarca

Department of Economics (mc 144)

University of Illinois at Chicago

601 S. Morgan Street

Chicago, IL 60607-7121

USA

E-mail: akarca@uic.edu

\footnotetext{
" This paper is forthcoming in Electoral Studies, 2007. Earlier versions were presented at the 2005 Annual Conference of the Economic Research Forum (ERF) held in Cairo, Egypt, and at the 2005 Annual Meeting of the Illinois Economic Association (IEA) held in Chicago, Illinois, USA. We have benefited greatly from the comments we have received from the audiences at these meetings. The detailed comments and suggestions given to us by Hassan Aly, our discussant at the ERF conference, Frank Tachau, our discussant at the IEA meeting, Ayşe Ayata, Mustafa Türkeş and two anonymous referees of the Electoral Studies were especially valuable. We are thankful to Cengizhan Güder for guiding us to the sources of data, and to Houston H. Stokes and Jin Man Lee for helping and advising us on computational matters. We also gratefully acknowledge the financial support given to us by the ERF.
} 


\section{Introduction}

According to the literature on economic voting, voters enter the voting booth with a number of considerations on their minds. They want to cast their ballots to reward incumbent parties for a good economic performance and to punish them for a bad one. They also try to support parties that represent their economic interests and ideologies. Furthermore, they attempt to vote strategically, for example to diffuse power. Researchers studying the impact of these factors on election outcomes face two basic data-related problems. First, time-series data is scarce. They are realized at the rate of one observation every four years or so. Second, variables that are typically used to represent economic performance are often autocorrelated, and crosscorrelated with socioeconomic variables used to represent economic interests and ideological leanings of the electorate.

The first problem makes time-series studies in this area very difficult, if not impossible, except for countries such as the United States where elections are held regularly, under the same rules, and for centuries. For countries like Turkey on the other hand, although the history of contested elections exceeds half a century, due to military interventions, party closures and frequent changes in election laws, consistent time-series data of sufficient length are hard to come by. The second problem creates difficulties in estimating separate impacts of recent and distant economic performance and of different socioeconomic factors, on election results.

To remedy the first problem, non-U.S. studies have often resorted to pooling different types of elections involving multiple nations with different political systems, cultures and levels of development. While the findings of such studies can provide us with some insights on the significance and direction of the impact of economic and social variables on election outcomes, their applicability to individual countries is questionable, as the magnitudes of their estimates vary considerably from study to study. For a large country like Turkey which exhibits wide social and economic variation across its regions, a better approach to solving the first problem may be to use cross-provincial data for one or more elections, provided that the elections involved are fairly contested and are not held under the shadow of an extraordinary non-economic event.

Since controlled experimentation is not possible in this area, the solution to the second problem require some luck in finding suitable data. In this regard, the results of the 1995 Turkish parliamentary election, at the provincial level, provide us with a unique opportunity. The same coalition government, headed by the same prime minister, was in power during the election year and the year preceding it. The 
election was fairly contested, unlike the ones in 1983, 1999 and 2002 for example, when some parties and/or political leaders were banned from entering the election. In fact, the 1995 election not only resulted in transfer of power to a new coalition, a far-right pro-Islamist party emerged from it as the top vote-getter, a first in Turkish history. Also, unlike the election held in 1999, no major event such as the capture of the long-sought leader of the terrorist organization PKK dominated the voting in 1995. Most importantly, the economic conditions in the two years preceding the election were quite different from each other. ${ }^{1}$ The correlation coefficient between provincial growth rates in per capita real GDP in 1994 and 1995 is literally zero, as if the data were generated by a designed experiment. The correlation coefficient between these economic performance indicators and each of the key socioeconomic indicators used to capture various economic interests and ideologies among the voters, such as the provincial urbanization rate, the net migration rate, the mean years of schooling, and proportion of women in non-agricultural employment, are all almost zero. While the correlation between the socioeconomic variables mentioned are somewhat higher, they are still quite low.

Our purpose in this paper is to take advantage of the unusual opportunity provided by the 1995 Turkish election and circumstances surrounding it, to study the impact of economic and social factors on election outcomes. In particular we will investigate whether voters 1) take government's economic performance into consideration in casting their ballots and if so, 2) whether they place as much weight on the distant past as they do on the recent past, 3 ) whether they hold major and minor parties in a governing coalition equally accountable, 4) whether they apportion the votes they switch to or from the incumbent parties due to economic performance, evenly among the opposition parties, 5) whether they exhibit a tendency to vote against the parties in power, either to create checks and balances against concentration of power, or to try new parties, or out of disappointment with the controversial decisions made by these parties, 6) whether they exhibit any bias in favor of or against any of the parties, and 7) whether their location (urban or rural, an area with positive or negative net migration rate), level of education, degree of conservatism or religiosity, make a difference on their vote.

Answers to the above questions are relevant not only for understanding and predicting election outcomes but also for understanding the sources of economic and political instability. For example, when the electorate emphasizes recent past over distant past, the governments will be provided with incentives to undertake populist policies before an election and deal with their adverse long-run consequences after the election, giving rise to political business cycles. The administrations then will also be motivated to postpone, until after elections, the adjustments needed for the longrun health of the economy, when such measures involve short-run hardships. When 
voters do not hold all parties in a coalition government equally accountable, this could lead to irresponsible behavior by some parties in power and may create friction between the coalition partners, which in turn can lead to the dissolution of the government and to political instability. When the voters tend to vote for extremist parties to protest economic conditions, or for the opposition parties in general, to diffuse power or just to give them a chance or to show their displeasure with some of the decisions made by the incumbent parties, it will result in political fragmentation and polarization. While this may create more checks and balances for the democracy, it will also shorten the lives of governments. Then the country will be run frequently by inexperienced parties and leaders, and subjected to frequent elections. When the political choices of voters depend on such things as their residence in urban or rural area, their level of education, and the degree of their conservatism, rapid modernization and economic development may bring with it not only more sophisticated voters but also political instability, especially if the political parties are unable to adapt.

A considerable amount of research on other countries is devoted to investigating the above questions, perhaps with the exception of the fourth. Surveys of these are provided by Lewis-Beck (1988), Nannestad and Paldam (1994), Norpoth (1996) and Lewis-Beck and Stegmaier (2000). However, there are only a few studies on economic voting in Turkey. Notable among them are Bulutay and Yildirım (1969), Bulutay (1970), Çakmak (1985), Çarkoğlu (1997a), Esmer (2002), Genç, Şahin and Bekmez (2005), and Akarca and Tansel (2006). Of these, only the fourth, fifth, seventh, and to some extent the third one used rigorous statistical analyses. The rest based their conclusions on descriptive statistics only. The first four of these have addressed only the question of whether economic conditions prevailing at the time of an election affect its outcome, ignoring other important questions pertaining to voter behavior. The sixth one considered, in addition, the issue of voter myopia. The fifth one considered only the seventh question. Akarca and Tansel (2006) examined all of the questions except the fourth and the seventh. The first three studies considered only agricultural prices and output, as determinants of electoral outcomes. While the fourth and the sixth considered economy-wide variables in explaining the voter behavior, their results are suspect due to errors in their data. ${ }^{2}$

By studying all seven questions and studying them jointly (controlling for one another), doing this using a reliable and very suitable data set not analyzed before, and comparing our results to those found by other studies on Turkey and on other countries, we aim in this paper to fill a gap in the literature on economic voting in Turkey. By studying how the votes lost by incumbent parties, are distributed among the opposition parties, an issue neglected in other countries too, we hope to contribute to the economic voting literature in general as well. Finally, by studying the factors 
that contributed to the unprecedented rise of the pro-Islamist party in Turkey, we hope to shed some light on a phenomenon being observed not only in Turkey but in other Muslim countries too.

\section{The model}

We base our analysis on vote equations of the following form:

$V_{i j t}=a_{i}+b_{i} V_{i j t-4}+c_{i} G_{j t}+d_{i} G_{j t-1}+f_{i} S_{j t}+h_{i} U_{j t}+k_{i} P_{j t}+m_{i} N_{j t}+r_{i} W_{j t}+e_{i j t} \begin{aligned} & i=1,2, \ldots, 1 \\ & j=1,2, \ldots, n\end{aligned}$

where

1 : the number of parties participating in the election held in year $t$,

$\mathrm{n}$ : the number of provinces,

$\mathrm{V}_{\mathrm{ijt}}$ : the vote share of party $\mathrm{i}$, in province $\mathrm{j}$, in the election held in year $t$,

$\mathrm{V}_{\mathrm{ijt}-\mathrm{4}}$ : the vote share of party $\mathrm{i}$, in province $\mathrm{j}$, in the previous election held approximately four years earlier,

$\mathrm{G}_{\mathrm{jt}}$ : the growth rate of per capita real GDP, in province $\mathrm{j}$, in year $\mathrm{t}$ (the election year),

$\mathrm{G}_{\mathrm{jt}-1}:$ the growth rate of per capita real GDP, in province $\mathrm{j}$, in year $\mathrm{t}-1$ (the year preceding the election year),

$S_{j \mathrm{t}}$ : mean years of schooling of the population over age 6 , in province $\mathrm{j}$, in year $\mathrm{t}$,

$\mathrm{U}_{\mathrm{jt}}$ : proportion of urban residents in the population of province $\mathrm{j}$, in year $\mathrm{t}$,

$\mathrm{P}_{\mathrm{jt}}$ : the net migration rate in province $\mathrm{j}$, between years $t$ and $t-5$, if the rate is positive, and zero otherwise, ${ }^{3}$

$\mathrm{N}_{\mathrm{jt}}$ : $\quad-1$ times the net migration rate in province $\mathrm{j}$, between years $t$ and $\mathrm{t}-5$, if the rate is negative, and zero otherwise,

$\mathrm{W}_{\mathrm{jt}}$ : proportion of women in the non-agricultural employment in province $\mathrm{j}$, in year $\mathrm{t}$,

$e_{i j t}$ : the disturbance term for party $i$, in province $j$, in year $t$,

and $a_{i}, b_{i}, c_{i}, d_{i}, f_{i}, h_{i}, k_{i}, m_{i}$ and $r_{i}(i=1,2, \ldots . .1)$ are parameters to be estimated. The variables, $\mathrm{V}_{\mathrm{ijt}}, \mathrm{V}_{\mathrm{ijt}-4}, \mathrm{G}_{\mathrm{j} t}, \mathrm{G}_{\mathrm{jt}-1}, \mathrm{U}_{\mathrm{j} t}, \mathrm{P}_{\mathrm{j},}, \mathrm{N}_{\mathrm{jt}}$, and $\mathrm{W}_{\mathrm{jt}}$ are measured in percentage points. Henceforth, we will refer to $\mathrm{G}_{\mathrm{jt}}$, as the growth rate, $\mathrm{U}_{\mathrm{jt}}$, as the urbanization rate, and to $\mathrm{P}_{\mathrm{jt}}$ and $\mathrm{N}_{\mathrm{jt}}$, as the positive and negative migration rates, respectively.

The motivation for including $\mathrm{G}_{\mathrm{jt}}$ in our regressions of course is to measure the impact of government's recent economic performance on election outcomes. We would expect the coefficients of this variable to be positive for the incumbent parties 
and negative for at least some of the opposition parties. In other words, good economic performance should favor incumbents at the expense of opposition parties. This coefficient will be significantly negative for those opposition parties which attract the protest vote for poor economic performance. $G_{\mathrm{jt}-1}$ is considered so that we can determine whether voters take earlier periods of administrations into account in making their evaluations. If the results of the time-series study by Akarca and Tansel (2006) on Turkish elections and the results of both time-series and cross-section studies of others on other countries are any guide, the coefficient of $\mathrm{G}_{\mathrm{jt}-1}$ should be close to zero and insignificant in all equations. If significant, the coefficient of $\mathrm{G}_{\mathrm{jt}-1}$ is expected to be less than that of $\mathrm{G}_{\mathrm{jt}}$, in absolute value. This would imply a decay in voters' memories over time. ${ }^{4}$

We would expect the coefficient of $\mathrm{V}_{\mathrm{ijt}-\mathrm{k}}$ to be close to unity due to strong inertia in the political system. However, this coefficient is likely to be significantly less than one for the incumbent parties and equal to or greater than one for the opposition parties. There are two reasons for this. First, some voters are likely to vote strategically against parties in power to dilute their power. Second, it is almost impossible for the ruling parties not to alienate some of their supporters with the compromises they make while in office, which goes against the interests and ideologies of these supporters. The voters may also get tired of the parties or leaders in power with the passage of time, and decide to give others a chance. Political scientists sometimes refer to this depreciation in the political capital of incumbent parties as the "cost of ruling." Unfortunately, in a cross-section study, it is not possible to separate "cost of ruling" from "strategic voting" since the time spent in power by the incumbent parties is the same for each observation (province), unlike in a time-series study where it varies from observation to observation (election to election). Thus, in the present study, the estimated coefficients of the lagged vote share variable will capture the combined impact of both of these factors.

Economic interests and ideologies of voters depend, at least to some extent, on whether they are educated or not, and whether they live in an urban or a rural location. $S_{\mathrm{jt}}$ and $\mathrm{U}_{\mathrm{jt}}$ are included in the vote equations to capture the impact of these two factors on the vote shares of various political parties. Also, the needs and voting habits of people who have migrated to a province recently are likely to differ from those of long-time residents. The variable $\mathrm{P}_{\mathrm{jt}}$ is considered to gain some insight as to which parties are preferred by the recent immigrants. This variable stands, at the same time, for the overall attractiveness of social and economic conditions in a province that gives it its degree of "pull." Likewise, $\mathrm{N}_{\mathrm{jt}}$ measures the degree of "push" by the existing conditions in a province. Consequently, these two variables reflect also, the level of satisfaction or dissatisfaction of all residents of the province with the conditions prevailing in that province. Also, the problems in provinces with 
predominantly push and predominantly pull factors are likely to be different and are not likely to be addressed by the parties equally well. Furthermore, the impact of a party's proposed policies, on provinces with a negative net migration rates, need not be the mirror image of their impact on provinces with positive net migration rates. Consequently, we created two separate variables, $\mathrm{P}_{\mathrm{jt}}$ and $\mathrm{N}_{\mathrm{jt}}$, from the net migration rate variable, to allow for and measure differential responses by the electorates in provinces exhibiting a net pull and in those exhibiting a net push. $\mathrm{W}_{\mathrm{jt}}$ is considered as a proxy for the degree of conservatism and/or religiosity of the voters in a province. Highly conservative and devoutly religious families in Turkey tend to oppose female members of their families to work outside the home, unless it is with other family members in an agricultural setting. Thus we thought that the proportion of women in non-agricultural employment in a province would be a good indicator of the proportion of voters in that province who can be categorized as conservative/religious ${ }^{5}$. The estimated coefficients of this variable will enable us to identify the parties with which the conservative and religious voters feel an ideological kinship. The constant terms are in the vote equations to capture any bias, in existence at the time of the election, in favor of or against any of the parties.

\section{The political background}

Turkey is a parliamentary democracy. Its election system is based on proportional representation. There are 550 seats in the parliament (Turkish Grand National Assembly) since the 1995 election. This figure was 450 during the period 1961-1991, except for the 1983 election when it was 400. The seats are filled through elections that take place in multi-member electoral districts. ${ }^{6}$ The president is elected by the parliament who in turn appoints the prime minister. The prime minister and the cabinet he or she heads, takes office only after receiving a vote of confidence from the parliament.

To fit our model, we have chosen the results of the 1991 and 1995 parliamentary elections in Turkey. The former enter the equations as an independent variable and the latter as the dependent variable. Both of these elections were fairly contested and were not surrounded by any extraordinary events. These elections were the third and fourth parliamentary elections since the return to democracy following the 1980 military take-over and the fifth and seventh elections since that time if the local elections, which are held simultaneously in Turkey, are counted as well. As a sign of their fairness, in both 1991 and 1995 elections, incumbent parties have lost substantial amounts of votes, and in each one, an opposition party came on top. In the case of the 1995 election, a far-right pro-Islamist party came first which was an unprecedented occurrence in Turkish history. Furthermore, in the 1991 and 1995 elections, unlike the ones in 1983, 1999 and 2002 for example, no political leaders or 
parties were banned. Unlike the 1999 election, no major event such as the capture by government of long-sought Abdullah Öcalan, the leader of the terror organization PKK, dominated the voting.

Major political parties which participated in the 1991 and 1995 elections, their Turkish acronyms, and their nationwide vote shares are presented in Table 1. Combined vote shares of these parties were 99.4 and 97.9 percent of the totals in 1991 and 1995, respectively. ${ }^{7}$ These parties include all of those that exceeded in 1995 the nationwide 10 percent threshold necessary to be represented in the parliament, plus the Nationalist Action Party (MHP) and the People's Democracy Party (HADEP), which while falling below this threshold, received sizable portion of the votes. ${ }^{8}$ We should note that the Republican People's Party (CHP) and the People's Democracy Party (HADEP) were not in existence at the time of the 1991 election, and the Nationalist Action Party (MHP) was named Nationalist Work Party (MÇP) then. As is commonly done, we took the Republican People's Party and the People's Democracy Party to be continuation of the Social Democratic Populist Party (SHP) and the People's Work Party (HEP) respectively, which were in existence in 1991. To convey the appropriateness of this assumption, a brief discussion of the histories of these parties would be in order. The Republican People's Party, which was virtually the only party in Turkey until 1946 and one of two largest parties between 1946 and 1980, was closed, as were all of the other political parties, by the military regime which masterminded the 1980 coup-detat. By 1985 the leaders and supporters of this party have regrouped in two distinct parties: the Social Democratic Populist Party (SHP) and the Democratic Left Party (DSP). Both of these parties entered the 1987 and 1991 elections. In 1992, after the passage of the law allowing the reopening of the parties closed in 1981 by the military regime, the Republican People's Party (CHP) was reopened. Ten months before the 1995 election, Social Democratic Populist Party (SHP) joined the Republican People's Party (CHP). The People's Work Party (HEP) was formed by some ethnic Kurdish leaders in 1990. It was closed by the Constitutional Court in 1993, for supporting the secession of a portion of the country and for following the orders of the banned terror organization PKK. The leaders and the rank and file of the party which escaped being banned, quickly reorganized and formed the People's Democracy Party (HADEP) in 1994. The latter party is universally accepted as the successor of the former party. ${ }^{9}$

The Nationalist Action Party (MHP), then named Nationalist Work Party (MÇP), entered the 1991 election in partnership with the Welfare Party (RP) and under the banner of the latter. ${ }^{10}$ Thus the votes cast for the Welfare Party (RP) in 1991 should be thought of as the sum of the votes for the two parties. Likewise, the Social Democratic Populist Party (SHP) and People's Work Party (HEP) entered the 1991 elections in partnership as well, under the banner of the former. Consequently, 
vote share of the Social Democratic Populist Party (SHP) in 1991 is really the sum of the vote shares of the two parties in question.

Of the parties in the table, the True Path Party (DYP) and the Motherland Party (ANAP) represent, ideologically, the center-right, the Republican People's Party (CHP) and the Democratic Left Party (DSP), the center-left, and the Nationalist Action Party (MHP) and the Welfare Party (RP), the far-right. Whereas the Nationalist Action Party (MHP) is Turkish-nationalist, the Welfare Party (RP) is proIslamist. ${ }^{11}$ The People's Democracy Party (HADEP) has a leftist ideology and is considered to be Kurdish-nationalist. It is essentially a regional party, receiving its votes predominantly from ethnic Kurds living in some of the the less-developed southeastern and eastern provinces. Its support is much less in other regions of the country, where one third to one half of the Kurds are believed to live now, as a consequence of steady migration over the past several decades.

Between the 1991 and 1995 elections a True Path Party - Republican People's Party (earlier, True Path Party - Social Democratic Populist Party) coalition government was in power, with the former as the major partner. In 1993, following the election of the True Path Party (DYP) leader Süleyman Demirel to presidency, prime ministership passed to the new leader of the party, Tansu Çiller, making her the first woman to head a Turkish government. For more detailed discussion of the 1995 Turkish parliamentary election and the events surrounding it, we refer the reader to Tuncer (1996) and Çarkoğlu (1997b).

\section{The data}

The sources of our data are Tuncer (1996) and the State Institute of Statistics (1998) (for the computation of the vote shares in 1991 and 1995), the State Planning Organization (2002) (for the computation of the growth rates in 1994 and 1995), the State Institute of Statistics (2003) (for the computation of the mean years of schooling, the urbanization rate, and the proportion of women in non-agricultural employment), and the State Institute of Statistics (2005) (for the computation of the net migration rate). The latter two references report the data from the 2000 census. The data necessary for the computation of the mean years of schooling, the urbanization rate, the net migration rate, and the proportion of women in the nonagricultural employment, are available only for the census years. Consequently, we were forced to use the 2000 values of these variables for the year 1995, presuming the figures for the two years in question are approximately the same. 
In computing mean years of schooling for each province, we attributed 15, 11, 8 , and 5 years of schooling respectively, to university, high school, middle school, and primary school graduates in the province. Following Tansel and Güngör (1997), we assigned two years worth of schooling to those who are literate but not a graduate of any school. Children under age six, are omitted in computing the average. Urban population is taken as the population living in the provincial and district capitals, as it is defined by the State Institute of Statistics.

Some aggregation and disaggregation of the data was necessitated by the changes in the administrative division of the country between 1991 and 1995. At the time of the 1991 elections the country was divided into 74 provinces. However one of these was partitioned into three, in the following year, and three of them into two, shortly before the 1995 election. Because the 1993-1995 GDP data are not available for the provinces created in 1995 but they are for the original provinces from which these emerged, we recomposed the latter and pretended that the 1995 election took place in 76 provinces instead of 79. ${ }^{12}$ Since the GDP and vote data exist for the parts of the province partitioned in 1992, we disaggregated the 1991 vote data for the province and acted as if the 1991 election was also held in the same 76 provinces we had assumed for $1995 .^{13}$

Lack of separate vote data in 1991 for the Welfare Party (RP) and the Nationalist Action Party (MHP) which entered the election in partnership, forced us to aggregate their votes in 1995 as well and treat them as if they were one party. Since both of these parties are extreme right wing parties and both were opposition parties in 1991, this does not constitute a major problem for our purposes. Treating the Republican People's Party (CHP) and the People's Democracy Party (HADEP), whose predecessors entered the 1991 election in alliance, in a similar manner, on the other hand, would defeat the purpose of our study, since one of these was an incumbent party and the other, an opposition party in 1995. Consequently, we were forced to use the 1991 vote share of Social Democratic People's Party (SHP), as a proxy for $\mathrm{V}_{\mathrm{ijt}-4}$ for both the Republican People's party (CHP) and the People's Democracy Party (HADEP). Of course, this would artificially inflate the votes lost by the Republican People's Party (CHP) between 1991 and 1995 due to strategic voting and cost of ruling, in provinces with significant People's Democracy Party (HADEP) presence. As these provinces are also the ones with disproportionately negative growth rates in 1994 and 1995, this approach would also bias our results in favor of finding a strong positive relationship between economic performance and vote share of the Republican People's Party (CHP). To alleviate the problem, we have eliminated from our sample 14 provinces in which People's Democracy Party (HADEP) has received more than 8.34 percent of the vote in $1995 .{ }^{14}$ This eliminated 7 out of 8 provinces in the Southeast and 7 out of 14 provinces in the East. ${ }^{15}$ By excluding these provinces, in fact we have hit two birds with one stone. These 
provinces were also the ones where government forces were fighting the PKK insurgents. Thus different concerns and dynamics were at play at these than the rest of the country. ${ }^{16}$

The descriptive statistics for our sample of 62 provinces are given in Table 2. It can be observed there that all of the variables exhibit a great variation. We should also mention that the correlation coefficient between the growth rates in 1994 and 1995 is zero. The correlation between the two growth rate variables and the socioeconomic variables: the mean years of schooling, the urbanization rate, the negative and positive migration rates, and the proportion of female workers in nonagricultural employment, vary in the 2 percent to 26 percent range. The correlation among the socioeconomic variables mentioned, are quite low as well, ranging from 8 to 40 percent.

\section{Empirical results}

The party vote equations obtained by fitting model (1) to cross-provincial data, using the method of Ordinary Least Squares (OLS), are given in Table 1. These include, besides the estimates of parameters and their t-statistics in absolute value, the $\mathrm{R}^{2}$, the adjusted $\mathrm{R}^{2}$, and $\mathrm{F}$ values, for judging the fit of the equations, and White's (1980) chi-square statistics and their probability values to check for heteroscedasticity in the residuals and any misspecification in the equations considered. The equations fit the sample well in the cases of the True Path Party (DYP), the Republican People's Party (CHP), the Motherland Party (ANAP), the Democratic Left Party (DSP) and the Welfare Party + Nationalist Action Party (RP+MHP), and exhibit no heteroscedasticity in their residuals and give no indication of misspecification whatsoever. In the case of People's Democracy Party (HADEP) however, the fit is not as good.

To make sure that the results obtained are not driven by a few outliers or influential observations, we have estimated all of the equations also using the robust regression procedure suggested by $\mathrm{Li}$ (1985). This technique eliminates outliers and downweights observations with large absolute residuals. The robust regressions are presented in Table 4. These are almost identical to the OLS regressions given in Table 3, for all parties except the People's Democracy Party (HADEP). For the latter, the coefficient estimates and their t-values are drastically different under the two estimation methods. The F-value for the robust regression for this party is not significant at conventional levels. Consequently, the vote equations we have estimated for People's Democracy Party (HADEP) can not be used to make reliable inferences. It appears that the behavior of this party's voters not only differ from those of other parties but differ across the provinces as well. Probably these voters are motivated 
predominantly by ethnic factors. This phenomenon needs to be investigated further through other studies. Henceforth we will confine our analysis to the remaining six parties which received collectively 94 percent of the eligible votes cast in 1995 . For these, the differences in the coefficient estimates and their t-values reported in tables 3 and 4 are negligible. Therefore it makes no difference on which table we base our analysis. Only two notable differences exist between the two tables in question. The coefficient of urbanization variable is significant for the Democratic Left Party (DSP) in robust regression but not so in the OLS regression. Also, the coefficient of the lagged vote share variable is a little higher in the robust regressions than in the OLS regressions, in the cases of the Motherland Party (ANAP) and the Democratic Left Party (DSP), but a little lower in the case of the Republican People's Party (CHP). In drawing conclusions involving these parameters, we will rely on robust regressions.

The estimated coefficient of the lagged vote variable is found to be significantly higher than zero for all of the parties. As expected, the coefficient is significantly below unity for the two incumbent parties, but either about unity or greater than unity in the cases of the opposition parties. Thus the data supports the existence of the strategic voting and/or the cost of ruling effects. It appears that, in 1995, the Democratic Left Party (DSP) was the main beneficiary of these effects at the expense of the incumbent parties. Although this party has not participated in any of the governments formed prior to 1995, and its leader since 1978, it is not possible to determine from a cross section data, how much of the party's vote share was due to this and how much of it is attributable to strategic voting. It may be interesting to note that Democratic Left Party came in first in the next election held in 1999. It looks like in four years time, the True Path Party (DYP), the major incumbent party, has lost 45 percent of its vote share, holding other factors constant. The depreciation in the political capital of the Republican People's Party (CHP), the minor incumbent party, appears to be a little more.

The coefficient of contemporaneous growth rate is estimated to be positive and significant for the True Path Party (DYP), the major incumbent party. The estimated coefficient of the lagged growth rate however, is substantially smaller and not significantly different from zero. Thus, it is evident that the Turkish voters take economic performance into account in casting their ballots but that they place no weight on distant past in making their assessments. For each percentage point increase in the election year growth rate, the primary incumbent party is expected to receive an additional 0.26 or 0.27 percent of the total vote. On the other hand, the estimated coefficients of both growth rate variables are insignificant, and have opposite of the expected sign, for the Republican People's Party (CHP), the minor partner in the coalition. Therefore, it appears that only the major incumbent party is held responsible by the voters for economic performance. The estimated parameter of the growth rate is negative and significant only for the Welfare Party + Nationalist 
Action Party (RP+MHP) and is about equal to that of True Path Party (DYP), in absolute value. Thus, it seems that the protest vote generated by a poor economic performance of government is channeled to the extremist nationalistic and religious opposition parties. The government's performance does not appear to impact the vote shares of the opposition parties in the center. The estimated parameter of the lagged growth rate is not significant for any of the opposition parties, confirming once more that the voters are myopic in assessing economic performance.

Our results indicate that the party choice of Turkish voters are also affected by their socioeconomic characteristics. Controlling for other factors, the True Path Party (DYP) receives its votes disproportionately from rural provinces. This should not be surprising as this party champions the causes of villagers. Each percentage decrease in the urbanization rate of a province adds 0.12 percentage points to the True Path Party's (DYP's) vote share in that province. The party's vote share is postively related to the positive migration rate. For each percentage point increase in the positive net migration rate of a province, the True Path Party's (DYP's) vote share in that province rises by 0.65 to 0.75 percentage points. This can be viewed essentially as the combined effect of two factors. First, most of the migrants have rural roots. They are most likely to have migrated to a bigger city, either directly from a village, or from a smaller town to which they have moved earlier from a village. The voting habits of these people are not likely to change immediately upon relocation, and their connections to their original places of residence are not likely to be severed completely. It appears that many of them still favor the True Path Party (DYP), as they did before. Second, the higher is the positive migration rate in a province, the better are the social and economic conditions there, and the more satisfied are the voters, whether they are recent immigrants or long-time residents. It appears that the voters residing in provinces with good living conditions, are giving some of the credit for it to the major party in power.

The Republican People Party's (CHP's) vote share on the other hand appears to be concentrated among the more educated voters. An additional year of schooling on the average, is estimated to raise that party's vote share in a province by slightly less than 3 percentage points. Indeed, this party strongly favors state intervention in economic, social and cultural affairs. It resists privatization of state owned enterprises and all attempts to reduce the size of the government. Consequently, it receives a strong support from the government bureaucracy which incorporates a sizable portion of the educated population. The party also appears to receive relatively less votes in urban areas, controlling for education and other factors.

Unlike the Republican People's Party (CHP), the vote share of the Democratic Left Party (DSP), the other center left party, is related to education negatively and to urbanization positively. This party's vote share declines by 2.4 percentage points for 
each year of increase in mean years of schooling but rises by 0.08 percentage points for each percentage increase in provincial urbanization rate. Thus among the left leaning voters, the Republican People's Party (CHP) seem to be favored by the more educated and less urbanized, and the Democratic Left Party (DSP), by the less educated and more urbanized. The votes of the Democratic Left Party (DSP) are also concentrated in less conservative regions of the country, as indicated by the significantly positive coefficient of the variable representing the share of women in non-agricultural employment. A percentage point increase in this proportion contributes 0.22 to 0.34 percentage points to the party's vote share. On the other hand, the party's showing in provinces where social and economic conditions push people into emigrating, is particularly poor. This is ironical because the party, and its leader Bülent Ecevit, is known to champion a policy designed to keep people from emigrating, through creation of large size villages with better amenities. Voters who are supposed to be helped by this policy apparently reject it.

Unlike the Democratic Left Party (DSP), the Motherland Party (ANAP) must be giving more hope to people living in provinces with poor social and economic opportunities, as its vote share is disproportionately higher in such provinces. For each percentage point increase in the absolute value of negative net migration rate, the Motherland Party (ANAP) is estimated to gain a little more than half a percent of the vote and the Democratic Left Party (DSP) to lose approximately that much.

The Welfare Party (RP) and Nationalist Action Party (MHP), in addition to attracting the votes of those protesting the government's economic performance, appear to gather votes also from the conservative/religious people. Their vote increases by 0.7 percentage points for each percentage drop in the share of women in non-agricultural employment.

Among the socioeconomic variables considered, education, push factors and conservatism appear to not matter for the True path Party (DYP), the pull and push factors and conservatism for the Republican People's Party (CHP), education, urbanization, pull factors and conservatism for the Motherland Party (ANAP), pull factors for the Democratic left Party (DSP), and education, urbanization and pull and push factors for the Welfare Party + Nationalist Action Party (RP+MHP).

The constant terms for the True Path Party (DYP), and the Democratic Left Party (DSP) are not significantly different from zero. However, this term is significantly negative for the Republican Party (CHP) and the Motherland Party (ANAP), but significantly positive for the Welfare Party + the Nationalist Action Party (RP+MHP). Thus a significant shift of votes from the center Motherland and Republican People's parties (ANAP and CHP) to extreme right Welfare and 
Nationalist Action parties (RP and MHP), is observed, controlling for other factors. In hindsight, one can see that the outcome of the 1995 election was a precursor for the 1999 and 2002 elections. In 1999, Republican People's Party (CHP), and in 2002, the Motherland Party (ANAP), failed to make the 10 percent threshold to be represented in the parliament. The Nationalist Action Party came in second in 1999, and the successor party to the Welfare Party (RP), the Justice and Development Party (AKP) came on top in 2002.

We should also note that we have tried in our equations, as additional variables, the level of per capita GDP, the proportion of non-agricultural employment in total employment (as well as finer sectoral breakdowns of the employment), and the population density. However, none of these proved to be significant, no doubt because these variables are strongly correlated with the education and urbanization variables already in the model. Also, eliminating all of the socioeconomic variables from the equations resulted in similar coefficient estimates and t-values for the growth rate and its lagged value. Thus our conclusions concerning voter myopia appears to not depend on the choice of other variables in the equations. Furthermore, we have estimated equations (1) as a system of seemingly unrelated regressions (SUR) as proposed by Zellner (1962). That yielded almost identical results to the ones presented in tables 3 and 4 , for all of the parties we have analyzed. ${ }^{17}$ Thus we can claim that our results are robust with respect to the estimation method used as well.

\section{Comparisons with other studies}

Our main conclusion in this paper that the state of the economy influences the Turkish voters in casting their ballots, is the same as the one we have reached in Akarca and Tansel (2006), analyzing nationally aggregated time-series data, on local and parliamentary elections in Turkey between 1950 and 2004. The majority of the studies on voters in other countries have reached similar conclusions as well. There are very few studies in the literature which fail to find a connection between economic growth and election outcomes. These studies involve predominantly the U.S. Congressional elections, such as Erikson $(1988,1990)$, Alesina and Rosenthal (1989 and 1995), Alesina, Londregan and Rosenthal (1993) and Lynch (2002). However, the conclusions of these have been challenged by Jacobson (1990), Kiewiet and Udell (1998) and Grier and McGarrity (2002), who argued respectively that when proper specification is utilized, when better data is used and when the incumbency of the congressional candidates running for office is accounted for, growth in per capita real income exhibits a significant influence on the outcomes of House of Representatives elections. 
Our finding that the growth rate more than a year before an election does not affect its outcome, is in conformity with the findings of Fair $(1978,1982,1988,1996$, 1999 and 2004) who studied this issue extensively in U.S. presidential elections. He concluded that the growth rate only during 2-3 quarters preceding the election matters for the incumbent party's vote share. In fact, studies that use the growth rate in output or in per capita output during the election year as the main economic determinant of the incumbent government's electoral success, either finding or assuming growth in earlier years to be irrelevant, abound in the literature. Beside Fair $(1978,1982,1988$, 1996, 1999 and 2004), these include time-series studies by Lewis-Beck and Rice (1984a), Burdekin (1988), Gleisner (1992), Chappell and Suzuki (1993), Alesina, Londregan and Rosenthal (1993, 1996), Alesina and Rosenthal (1995) and LewisBeck and Tien (1996) on U.S. presidential elections, by Kramer (1971), Lewis-Beck and Rice (1984b), Kiewiet and Udell (1998), and Grier and McGarrity (2002) on U.S. congressional elections, by Lewis-Beck (1997) on French presidential elections, Akarca and Tansel (2006) on Turkish parliamentary and local administration elections, cross-state time-series study by Peltzman (1987) on U.S. gubernatorial elections, cross-state study by Blackley and Shepard (1994) on a U.S. presidential election, election, pooled cross-national time-series studies by Powell and Whitten (1993) on 102 parliamentary elections in 19 industrialized countries, Pacek and Radcliff (1995) on 52 presidential elections in 8 developing countries, Wilkin, Haller and Norpoth (1997) on 38 parliamentary and presidential elections in 38 developed and developing countries, and Chappell and Veiga (2000) on 136 parliamentary elections in 13 Western European countries. However, Peltzman (1990) analyzing U.S. presidential, senatorial and gubernatorial election outcomes, using pooled crossstate time-series data, and Abrams and Butkiewicz (1995) analyzing the outcome of a U.S. presidential election, using cross-state data, concluded that voters consider information from the incumbent's whole term, not just its final year. Their results nevertheless indicate that voters give relatively more weight to recent past of an administration than its distant past. Strumpf and Phillippe (1999) analyzing U.S. presidential election results, utilizing pooled cross-state time-series data, found growth in per capita real personal income two years prior to an election to be most relevant to its outcome. Genç, Şahin and Bekmez (2005) who studied 10 National Assembly elections in Turkey between 1950 and 1991 have argued against voter myopia in the case of Turkish voters. However, their assertion is not based on any statistical testing but solely on the fact that in two elections (out of 10), the major incumbent parties won despite negative growth rates during the election years. ${ }^{18}$ Furthermore, their approach fails to control for other factors.

The studies cited above, with the exception of one, estimate the vote gained by the incumbent parties due to a percentage increase in the election year growth rate, 
to be within the range from 1.0 to 1.8 percent of the total vote, when the growth rate is measured as the percentage change in real GDP, real GNP or real income, and within the range from 0.2 to 1.4 percent, when the growth rate is measured as the percentage change in per capita real GDP, per capita real GNP or per capita real income. Strumpf and Phillippe's (1999) estimate of 3.0 in this regard can be considered an outlier. Our coefficient estimate of 0.27 is in the lower end of the 0.2 to 1.4 range and is much lower than the estimate of 0.88 obtained in Akarca and Tansel (2006), analyzing the 1950-2004 time-series data for Turkey. Thus, in assessing the government's competence, the Turkish voters seem to put more weight on the government's economic performance at the national level than its performance at the local level. Nevertheless, our conclusion here pertaining to the memories of voters is the same as the one reached in Akarca and Tansel (2006) time-series study.

Our other important finding, namely that voters distinguish between major and minor parties in a governing coalition and hold only the major incumbent party accountable for economic growth, is also supported by the few studies that examined this issue. Wilkin, Haller and Norpoth (1997) who analyzed 38 presidential and parliamentary elections in 38 developed and developing countries, Tucker (2001) who analyzed data from 10 post-communist parliamentary elections in 5 Eastern European countries, and Akarca and Tansel (2006) who analyzed time-series data on 25 Turkish parliamentary and local administration elections have reached, the same conclusion we have here.

According to our model, due to strategic voting by the electorate and due to cost of ruling, the major and the minor incumbent parties are anticipated to lose 45 to 55 percent of their vote shares, after ruling four years. In Akarca and Tansel (2006), a 38 percent erosion in the vote share of the major incumbent party, and a 51 percent erosion in the combined share of all incumbent parties, were estimated over a similar time period. A vote equation fitted by Çakmak (1985) to the cross-section data for the 1957 Turkish parliamentary election, implies a 43 percent vote loss after about 3.5 years of ruling for the sole incumbent party. What we have found here is almost the same as what was found in these studies.

Depreciation in the votes of incumbent parties is not unique to Turkey but well established in the literature. The magnitude and speed of the depreciation however varies from study to study. Whitten and Palmer (1999), analyzing a pooled data involving 142 elections in 19 industrialized democracies, measured the vote loss of incumbent parties between two elections to be 47 percent when the clarity of government's responsibility is high, 25 percent when it is mixed and only 11 percent when it is low. Chappell and Veiga (2000), who studied a pooled data involving 136 parliamentary elections in 13 Western European countries, found the vote loss by 
incumbent parties between elections to be typically about 30 percent. These estimates are not too different than ours.

To our knowledge there are no studies on how the votes lost by incumbent parties due their economic performance, strategic voting and cost of ruling are distributed among the various opposition parties. Consequently, we will not be able to compare our results to any study in that regard.

Although there are studies on other countries relating the socioeconomic characteristics of voters to the election outcomes, such as Fielding $(1998,2000)$, it makes sense to compare our findings in this area only to studies on Turkey. To our knowledge, Esmer (2002) is the only study on Turkey in this regard that goes beyond just the examination of descriptive statistics. His study analyzes a survey conducted immediately after the 1999 Turkish parliamentary election and can be considered a study on voter behavior. Being a micro study, it considers far more voter characteristics than we could with our aggregate data. Nevertheless, variables relating to the education, religiosity/conservatism and urbanization levels of voters are considered in both studies and their estimated impacts can be compared. In making such comparisons however, the reader need to keep in mind that Esmer studied a different election, did not control for political inertia, economic performance, strategic voting and cost of ruling, and had more than one variable representing the same phenomenon in his equations. We should further note that, in comparing our results to Esmer's, we will treat the Virtue Party (FP) as the successor party to the Welfare Party (RP), as is commonly done.

Esmer (2002) finds that the education level affects the votes of the Motherland Party (ANAP) and the Democratic Left Party (DSP) negatively, and exerts no influence on the votes of other parties. We concur with his result pertaining to the Democratic Left Party (DSP) but not to the Motherland Party (ANAP). Like him, we fail to find a relationship between the education level and the votes for the True Path Party (DYP), the Welfare/Virtue Party (RP/FP) and the Nationalist Action Party (MHP). However we find that the education level impacts the Republican People's Party votes very strongly. Actually, Esmer expresses a surprise at not obtaining a positive relation between years of schooling and votes for the Republican Party (CHP), and argues that the income variable in his equation probably picks up this effect. According to Esmer, urbanization level affects the Democratic Left Party (DSP) votes positively, the Nationalist Action Party (MHP) votes negatively, and the votes of other parties insignificantly. Again we concur with Esmer in regards to this finding concerning the Democratic Left Party (DSP). According to our results however, the votes of the Welfare Party + the Nationalist Action Party (RP+MHP) are not affected by urbanization at all, as is the case with the Motherland Party 
(ANAP). Furthermore, we find the True Path Party's (DYP's) and Republican People's Party's (CHP's) vote share and the urbanization rate to be inversely related. Esmer finds, as we do, that the support of the Welfare/Virtue Party (RP/FP) among the religious is very strong. He concludes that the True Path Party (DYP) is also favored by these voters but that the Republican People's party (CHP), the Motherland Party (ANAP) and the Democratic Left Party (DSP) receive their votes from those who support secularism. We on the other hand have concluded that the Welfare Party + the Nationalist Action Party (RP+MHP) and the Democratic Left party (DSP) are the only parties effected by the religiosity or conservatism of the voters, the former positively and the latter negatively.

\section{Conclusions}

Our statistical analysis of the 1995 Turkish election results and the social, economic and political conditions surrounding it, leads us to conclude that 1) Turkish voters take changes in economic conditions into consideration in casting their ballots. However, 2) they seem to not look back beyond the election year in making their assessments and 3) they seem to hold only the primary party in a coalition government responsible for their economic well being. 4) Only the extremist (nationalist and islamist) opposition parties appear to benefit from a poor performance by the government and suffer from a good one. 5) There is a tendency for the ruling parties to lose substantial portion of their votes due to the combined effects of strategic voting and cost of ruling, even though we were unable to measure these effects separately. 6) There was a bias in favor of the extremist parties in the 1995 election that can not be explained by social and economic conditions. 7) The choices made by the Turkish voters are found also to depend on their socioeconomic characteristics.

The above conclusions are essentially in conformity with the findings of studies on other countries. Thus the Turkish voters seem to not differ in their behavior from their counterparts in Europe, North America and elsewhere. The first, second, third and the fifth of the above conclusions are also the ones we have reached in Akarca and Tansel (2006) utilizing time-series data on 25 parliamentary and local administration elections in Turkey, and thus appear to be robust. Here we found further that islamist Welfare Party (RP) and nationalist Nationalist Action Party (MHP) received their votes in 1995, especially from people living in areas that are less modernized and suffering from lack of economic growth. The major incumbent center-right True Path Party (DYP) received its votes predominantly from rural and recently urbanized voters, besides from those living in regions experiencing good economic conditions and economic growth. Minor incumbent center-left Republican 
People's Party (CHP) drew its votes, in particular, from the educated but less urbanized voters, whereas opposition center-left Democratic Left Party (DSP), from the less educated but more modern and urbanized voters. Center-right Motherland Party (ANAP), appears to have appealed to the voters residing in areas with poor economic and social opportunities. The Democratic Left Party (DSP) on the other hand was disfavored by these voters.

Based on the above conclusions, we can suggest that at the root of the relatively short tenures of Turkish governments, their frequent indulgence in populist policies, the fragmentation and polarization in theTurkish party system, and the frequency of elections that are called sooner than their constitutionally mandated time, lie the behavior of the Turkish electorate. The rapid modernization, urbanization and education of the population, while helping make voters more sophisticated, by altering their party preferences, may also be contributing to political instability as a side-effect.

\section{References}

Abrams, B. A., Butkiewicz, J. L., 1995. The influence of State-level Economic Conditions on the 1992 U.S. Presidential Election. Public Choice 85, 1-10.

Akarca, A. T., Tansel A., 2006. Economic Performance and Political Outcomes: An Analysis of the Turkish Parliamentary and Local Election Results Between 1950 and 2004. Public Choice 129, 77-105.

Alesina, A., Londregan, J., Rosenthal, H., 1993. A Model of the Political Economy of the United States. American Political Science Review 87, 12-33.

Alesina, A., Londregan, J., Rosenthal, H., 1996. The 1992, 1994 and 1996 Elections: A Comment and a Forecast. Public Choice 88, 115-125.

Alesina, A., H. Rosenthal, H., 1989. Partisan Cycles in Congressional Elections and the Macroeconomy. American Political Science Review 83, 373-398.

Alesina, A., Rosenthal, H., 1995. Partisan Politics, Divided Government, and the Economy. Cambridge University Press, New York.

Blackley, P. R., Shepard, E. M., 1994. A Statistical Analysis of the Effect of Statelevel Economic Conditions on the 1992 Presidential Election. Public Finance Quarterly 22, 366-382. 
Bulutay, T., 1970. Türk Toplumsal Hayatında İktisadi ve Siyasal Gelişmeler (Economic and Political Developments in Turkish Social Life). SBF Dergisi 25, 79119.

Bulutay, T., Yıldırım, N., 1969. Türk Seçmenlerin Oy Verme Eğilimlerinde İktisadi Sebeplerin Üzerinde Bir Deneme (An Essay on Economic Reasons Behind the Voting Tendencies of the Turkish Electorate). SBF Dergisi 22, 7-39.

Burdekin, R. C. K., 1988. Economic Performance and the Determination of Presidential Elections in the U.S. The American Economist 32, 71-75.

Chappell, H. W., Suzuki, M., 1993. Aggregate Vote Functions for the U.S. Presidency, Senate, and House. Journal of Politics 55, 207-217.

Chappell, H. W., Veiga, L. G., 2000. Economics and Elections in Western Europe: 1960-1997. Electoral Studies 19, 183-197.

Çakmak, C., 1985. Türkiye'de 1950'li Yıllardaki Genel Seçimler Üzerine Bir Deneme (An Essay on Elections during the 1950s in Turkey). Middle East Technical University Studies in Development 12, 245-283.

Çarkoğlu, A., 1997a. Macroeconomic Determinants of Electoral Support for Incumbents in Turkey, 1950-1995. New Perspectives on Turkey 17, 75-96.

Çarkoğlu, A., 1997b. The Turkish General Election of 24 December 1995. Electoral Studies 16, 86-95.

Erikson, R. S., 1988. The Puzzle of Midterm Loss. Journal of Politics 50, 10111029.

Erikson, R. S., 1990. Economic Conditions and the Congressional Vote: A review of the Macrolevel Evidence. American Journal of Political Science 34, 373-399.

Esmer, Y., 2002. At the Ballot: Determinants of Voting Behavior. In: Sayarı, S., Esmer, Y. (Eds.), Politics, Parties and Elections in Turkey. Lynne Rienner Publishers, Boulder, pp. 91-114.

Fair, R. C., 1978. The Effect of Economic Events on Votes for President. Review of Economics and Statistics 60, 159-173. 
Fair, R. C., 1982. The Effect of Economic Events on Votes for President: 1980 Results. Review of Economics and Statistics 64, 322-325.

Fair, R. C., 1988. The Effect of Economic Events on Votes for President: 1984 Update. Political Behavior 10, 168-179.

Fair, R. C., 1996. The Effect of Economic Events on Votes for President: 1992 Update. Political Behavior 18, 119-139.

Fair, R. C., 1999. The Effect of Economic Events on Votes for President: 1996 Update. <http://fairmodel.econ.yale.edu/rayfair/pdf/1998ahtm.htm> (10 February 1999).

Fair, R. C., 2004. The Effect of Economic Events on Votes for President: 2000 Update. <http://fairmodel.econ.yale.edu/rayfair/pdf/2002dhtm.htm> (17 October,2004).

Fielding, D., 1998. The Social and Economic Determinants of Voter Behaviour: Evidence from the 1992 General Election in Scotland. Scottish Journal of Political Economy 45, 237-257.

Fielding, D., 2000. Social and Economic Determinants of English Voter Choice in the 1997 General Election. Public Choice 102, 271-295.

Genç, H., Şahin İ. H., Bekmez S., 2005. Homoeconomical Behavior of Turkish Electorate. Southwestern Journal of Economics 7, 1-24.

Gleisner, R. F., 1992. Economic Determinants of Presidential Elections: The Fair Model. Political Behavior 14, 383-394.

Grier, K. B., McGarrity, J.P., 2002. Presidential Party, Incumbency, and the Effects of Economic Fluctuations on House Elections, 1916-1996. Public Choice 110, 143162.

Jacobson, G. C., 1990. Does the Economy Matter in Midterm Elections? American Journal of Political Science 34, 400-404.

Kiewiet, D. R., Udell, M., 1998. Twenty-five Years After Kramer: An Assessment of Economic Retrospective Voting Based Upon Improved Estimates of Income and Unemployment. Economics and Politics 10, 219-248. 
Kramer, G. H., 1971. Short-term Fluctuations in U.S. Voting Behavior, 1896-1964. American Political Science Review 65, 131-143.

Lewis-Beck, M., 1988. Economics and Elections: The Major Western Democracies. University of Michigan Press, Ann Arbor.

Lewis-Beck, M. S., 1997. Who's the Chief? Economic Voting Under a Dual Executive. European Journal of Political Research 31, 315-325.

Lewis-Beck, M. S., Rice, T. W., 1984a. Forecasting Presidential Elections: A Comparison of Naive Models. Political Behavior 6, 9-21.

Lewis-Beck, M. S., Rice, T. W., 1984b. Forecasting U.S. House Elections. Legislative Studies Quarterly 9, 475-486.

Lewis-Beck, M. S., Stegmaier, M., 2000. Economic Determinants of Electoral Outcomes. Annual Review of Political Science 3, 183-219.

Lewis-Beck, M. S., Tien, C., 1996. The Future in Forecasting: Prospective Presidential Models. American Political Quarterly 24, 468-491.

Li, G., 1985. Robust Regression. In: Hoaglin, D. C., Mosteller, F., Tukey, J. W. (Eds), Exploring Data Tables, Trends, and Shapes. Wiley, New York, 281-340.

Lynch, G. P., 2002. Midterm Elections and Economic Fluctuations: The Response of Voters Over Time. Legislative Studies Quarterly 27, 265-294.

Nannestad, P., Paldam, M., 1994. The VP Function: A Survey of the Literature on Vote and Popularity Functions after 25 Years. Public Choice 79, 213-245.

Norpoth, H., 1996. The Economy. In: LeDuc, L., Niemi, R.G., Norris, P. (Eds), Comparing Democracies: Elections and Voting in Global Perspective. Sage, Thousand Oaks, 219-238.

Pacek, A. C., Radcliff, B., 1995. Economic Voting and the Welfare State: A CrossNational Analysis. Journal of Politics 57, 44-61.

Peltzman, S., 1987. Economic Conditions and Gubernatorial elections. American Economic Review 77, 293-297. 
Peltzman, S., 1990. How Efficient is the Voting Market? Journal of Law and Economics 33, 273-63.

Radcliff, B., 1988. Solving a Puzzle: Aggregate Analysis and Economic Voting Revisited. Journal of Politics 76, 413-434.

Powell, G. B., Whitten, G.D., 1993. A Cross-National Analysis of Economic Voting: Taking Account of the Political Context. American Journal of Political Science 37, 391- 414.

State Institute of Statistics, 1998. Results of General Election of Representatives (Results by Province and District, 6.11.1983; 29.11.1987; 20.10.1991; 24.12.1995). Prime Ministry, Republic of Turkey Ankara..

State Institute of Statistics, 2003. 2000 Census of Population: Social and Economic Characteristics of Population. Prime Ministry, Republic of Turkey, Ankara.

State Institute of Statistics, 2005. Table-2: İllerin Aldığı ve Verdiği Göç (Immigration and Emigration by Province). Prime Ministry, Republic of Turkey, Ankara. $</ /$ www.die.gov.tr/TURKISH/SONIST/goc/hb14122004t8.gif $>$ (12 July 2005).

State Planning Organization, 2002. Table-9: Gross Domestic Product Per Capita (According to Provinces). Prime Ministry, Republic of Turkey, Ankara. <//www.dpt.gov.tr/dptweb/ekutup99/i199/il99.html> (5 June 2002).

Street, J. O., Carroll, R. J., Ruppert, D., 1988. A Note on Computing Robust Regression Estimates via Iteratively Reweighted Least Squares. The American Statistician 42, 152-154.

Strumpf, K. S., Phillippe, J. R., 1999. Estimating Presidential Elections: The Importance of State Fixed Effects and the Role of National Versus Local Information. Economics and Politics 11, 33-50.

Tansel, A., Güngör, N. D., 1997. The Educational Attainment of Turkey's Labor Force: A Comparison Across Provinces and Over Time. METU Studies in Development 24, 531-547.

Tucker, J. A., 2001. Economic Conditions and the Vote for Incumbent Parties in Russia, Poland, Hungary, Slovakia, and the Czech Republic from 1990 to 1996. PostSoviet Affairs 17, 309-331. 
Tuncer, E., 1996. 24 Aralık 1995 Seçimi: Sayısal ve Siyasal Değerlendirme (24 December 1995 Election: A Quantitative and Political Evaluation). TESAV (Foundation for Social, Economic and Political Research), İstanbul.

White, H., 1980. A Heteroscedasticity Consistent Covariance Matrix Estimator and a Direct Test of Heteroscedasticity. Econometrica 48, 817-838.

Whitten, G. D., Palmer, H. D., 1999. Cross-National Analyses of Economic Voting. Electoral Studies 18, 49-67.

Wilkin, S., Haller, B., Norpoth, H., 1997. From Argentina to Zambia: A World Wide Test of Economic Voting. Electoral Studies 16, 301-316.

Zellner, A., 1962. An Efficient Method of Estimating Seemingly Unrelated Regressions and Tests for Aggregation Bias, Journal of the American Statistical Association 57, 348-368. 
Table 1

Vote Shares of Political Parties in 1991 and 1995 Elections in Turkey (\%)

\begin{tabular}{|l|c|c|}
\hline Political Parties & 1991 & 1995 \\
\hline $\begin{array}{l}\text { True Path Party } \\
\text { (DYP) }\end{array}$ & 27.03 & 19.18 \\
\hline $\begin{array}{l}\text { Republican People's Party } \\
\text { (CHP) }\end{array}$ & $20.75^{\mathrm{b}}$ & 10.71 \\
\hline $\begin{array}{l}\text { Motherland Party } \\
\text { (ANAP) }\end{array}$ & 24.01 & 19.65 \\
\hline $\begin{array}{l}\text { Democratic Left Party } \\
\text { (DSP) }\end{array}$ & 10.75 & 14.64 \\
\hline $\begin{array}{l}\text { Welfare Party } \\
\text { (RP) }\end{array}$ & 16.88 & 21.38 \\
\hline $\begin{array}{l}\text { Neople's Democracy Party } \\
\text { (HADEP) }\end{array}$ & $\mathrm{d}$ & \\
\hline $\begin{array}{l}\text { Independents } \\
\text { Other Parties and }\end{array}$ & 0.58 & 2.18 \\
\hline
\end{tabular}

a In paranthesis are the Turkish acronyms of political parties.

${ }^{b}$ Vote share of the Social Democratic Populist Party (SHP), which merged in 1995 with the Republican People's Party (CHP), following the reopening of the latter.

c Nationalist Action Party (MHP), then named Nationalist Work Party (MÇP), entered the election in partnership with and under the banner of the Welfare Party (RP).

d The predecessor party to People's Democracy Party (HADEP), People's Labor Party (HEP) entered the election in partnership with and under the banner of Social Democratic Populist Party (SHP).

Source: Tuncer (1996). 
Table 2

Descriptive Statistics ${ }^{\text {a }}$

\begin{tabular}{|c|c|c|c|c|}
\hline Variable & Mean & $\begin{array}{l}\text { Standard } \\
\text { Deviation }\end{array}$ & Minimum & Maximum \\
\hline \multicolumn{5}{|l|}{$\mathrm{V}_{\mathrm{ijt}}(1995):$} \\
\hline True Path Party & 20.02 & 6.88 & 8.15 & 40.35 \\
\hline Republican People's Party & 10.54 & 4.80 & 3.31 & 26.73 \\
\hline Motherland Party & 19.71 & 7.00 & 9.91 & 54.47 \\
\hline Democratic Left Party & 13.39 & 8.56 & 1.04 & 33.69 \\
\hline Welfare P. + Nat. Action P. & 32.17 & 12.42 & 9.11 & 56.98 \\
\hline People's Democracy Party & 2.09 & 1.89 & 0.62 & 7.87 \\
\hline \multicolumn{5}{|l|}{$\mathrm{V}_{\mathrm{ijt}-4}(1991):$} \\
\hline True Path Party & 28.27 & 8.53 & 6.57 & 62.61 \\
\hline Republican People's Party ${ }^{\text {b }}$ & 19.12 & 6.93 & 4.97 & 35.27 \\
\hline Motherland Party & 23.86 & 5.80 & 12.15 & 47.55 \\
\hline Democratic Left Party & 9.85 & 5.95 & 1.30 & 25.35 \\
\hline Welfare P. + Nat. Action P. & 18.48 & 10.10 & 3.74 & 40.55 \\
\hline People's Democracy Party ${ }^{\text {b }}$ & 19.12 & 6.93 & 4.97 & 35.27 \\
\hline $\mathrm{G}_{\mathrm{jt}} \quad(1995):$ & 4.47 & 3.89 & -4.15 & 16.90 \\
\hline $\mathrm{G}_{\mathrm{jt}-1}(1994):$ & -2.13 & 8.19 & -14.24 & 27.48 \\
\hline$S_{j t} \quad(2000):$ & 5.23 & 0.53 & 3.93 & 6.83 \\
\hline $\mathrm{U}_{\mathrm{jt}}(2000):$ & 55.15 & 12.61 & 26.06 & 90.15 \\
\hline$P_{j t} \quad(2000):$ & 0.97 & 2.05 & 0.00 & 9.68 \\
\hline $\mathrm{N}_{\mathrm{jt}}(2000):$ & 2.29 & 2.56 & 0.00 & 10.67 \\
\hline $\mathrm{W}_{\mathrm{jt}}(2000):$ & 13.30 & 4.31 & 5.32 & 23.39 \\
\hline
\end{tabular}

a Sample includes 62 observations on provinces in which the vote share of the People's Democracy Party (HADEP) was under 8.34 percent.

b Social Democratic Populist Party (SHP) vote share.

Source: Authors' computations. 
TABLE 3

Coefficient Estimates and Summary Statistics: OLS Regressions

\begin{tabular}{|c|c|c|c|c|c|c|}
\hline \multirow[b]{2}{*}{$\begin{array}{l}\text { Indep. } \\
\text { Variables }\end{array}$} & \multicolumn{6}{|c|}{ Equations (i) ${ }^{a}$} \\
\hline & $\begin{array}{l}\text { True Path } \\
\text { Party }\end{array}$ & $\begin{array}{c}\text { Republican } \\
\text { People's } \\
\text { Party }\end{array}$ & $\begin{array}{l}\text { Motherland } \\
\text { Party }\end{array}$ & $\begin{array}{l}\text { Democratic } \\
\text { Left } \\
\text { Party }\end{array}$ & $\begin{array}{c}\text { Welfare Party } \\
+ \\
\text { Nationalist } \\
\text { Action Party }\end{array}$ & $\begin{array}{l}\text { People's } \\
\text { Democracy } \\
\text { Party }\end{array}$ \\
\hline Constant & $\begin{array}{r}5.84 \\
(0.85)\end{array}$ & $\begin{array}{c}-10.30^{\mathrm{c}} \\
(2.09)\end{array}$ & $\begin{array}{l}-16.29^{\mathrm{c}} \\
(1.82)\end{array}$ & $\begin{array}{r}8.43 \\
(1.35)\end{array}$ & $\begin{array}{l}23.74^{b} \\
(3.01)\end{array}$ & $\begin{array}{l}6.50^{\mathrm{c}} \\
(2.25)\end{array}$ \\
\hline $\mathbf{V}_{\mathrm{ijt}-4}$ & $\begin{array}{l}0.55^{\mathrm{b}} \\
(9.14)\end{array}$ & $\begin{array}{c}0.57^{\mathrm{b}} \\
(11.45)\end{array}$ & $\begin{array}{l}0.99^{\mathrm{b}} \\
(9.26)\end{array}$ & $\begin{array}{c}1.24^{\mathrm{b}} \\
(13.00)\end{array}$ & $\begin{array}{c}0.93^{\mathrm{b}} \\
(12.46)\end{array}$ & $\begin{array}{c}0.09^{\mathrm{b}} \\
(3.26)\end{array}$ \\
\hline $\mathbf{G}_{\mathbf{j t}}$ & $\begin{array}{l}0.27^{\mathrm{c}} \\
(2.20)\end{array}$ & $\begin{array}{l}-0.11 \\
(1.23)\end{array}$ & $\begin{array}{r}0.17 \\
(1.12)\end{array}$ & $\begin{array}{c}0.02 \\
(0.14)\end{array}$ & $\begin{array}{l}-0.28^{c} \\
(1.97)\end{array}$ & $\begin{array}{l}-0.15^{b} \\
(2.83)\end{array}$ \\
\hline $\mathbf{G}_{\mathrm{jt}-1}$ & $\begin{array}{r}0.07 \\
(1.03)\end{array}$ & $\begin{array}{l}-0.03 \\
(0.62)\end{array}$ & $\begin{array}{l}-0.06 \\
(0.66)\end{array}$ & $\begin{array}{r}0.05 \\
(0.79)\end{array}$ & $\begin{array}{l}-0.09 \\
(1.05)\end{array}$ & $\begin{array}{c}0.01 \\
(0.32)\end{array}$ \\
\hline$S_{j t}$ & $\begin{array}{c}0.44 \\
(0.30)\end{array}$ & $\begin{array}{c}2.99^{b} \\
(2.77)\end{array}$ & $\begin{array}{c}2.36 \\
(1.27)\end{array}$ & $\begin{array}{l}-2.37^{\mathrm{c}} \\
(1.74)\end{array}$ & $\begin{array}{r}-0.10 \\
(0.06)\end{array}$ & $\begin{array}{l}-2.08^{b} \\
(3.29)\end{array}$ \\
\hline $\mathbf{U}_{\mathrm{jt}}$ & $\begin{array}{l}-0.12^{c} \\
(2.15)\end{array}$ & $\begin{array}{l}-0.10^{b} \\
(2.48)\end{array}$ & $\begin{array}{l}-0.03 \\
(0.50)\end{array}$ & $\begin{array}{c}0.04 \\
(0.86)\end{array}$ & $\begin{array}{c}0.06 \\
(0.93)\end{array}$ & $\begin{array}{c}0.08^{b} \\
(3.60)\end{array}$ \\
\hline $\mathbf{P}_{\mathrm{jt}}$ & $\begin{array}{l}0.65^{\mathrm{c}} \\
(2.09)\end{array}$ & $\begin{array}{r}0.05 \\
(0.23)\end{array}$ & $\begin{array}{l}-0.33 \\
(0.85)\end{array}$ & $\begin{array}{r}0.13 \\
(0.45)\end{array}$ & $\begin{array}{l}-0.07 \\
(0.20)\end{array}$ & $\begin{array}{r}0.19 \\
(1.42)\end{array}$ \\
\hline $\mathbf{N}_{\mathrm{jt}}$ & $\begin{array}{c}-0.21 \\
(0.84)\end{array}$ & $\begin{array}{c}0.05 \\
(0.27)\end{array}$ & $\begin{array}{c}0.65^{\mathrm{c}} \\
(1.99)\end{array}$ & $\begin{array}{l}-0.77^{b} \\
(3.05)\end{array}$ & $\begin{array}{c}-0.35 \\
(1.26)\end{array}$ & $\begin{array}{c}0.13 \\
(1.21)\end{array}$ \\
\hline $\mathbf{W}_{\mathrm{jt}}$ & $\begin{array}{c}0.13 \\
(0.81)\end{array}$ & $\begin{array}{l}-0.01 \\
(0.06)\end{array}$ & $\begin{array}{l}-0.01 \\
(0.07)\end{array}$ & $\begin{array}{l}0.34^{\mathrm{c}} \\
(1.99)\end{array}$ & $\begin{array}{l}-0.70^{b} \\
(3.38)\end{array}$ & $\begin{array}{c}0.03 \\
(0.43)\end{array}$ \\
\hline $\begin{array}{l}R^{2} \\
\text { Adj. } R^{2}\end{array}$ & $\begin{array}{l}0.77 \\
0.74\end{array}$ & $\begin{array}{l}0.74 \\
0.70\end{array}$ & $\begin{array}{l}0.65 \\
0.59\end{array}$ & $\begin{array}{l}0.87 \\
0.85\end{array}$ & $\begin{array}{l}0.91 \\
0.90\end{array}$ & $\begin{array}{l}0.43 \\
0.35\end{array}$ \\
\hline $\mathbf{F}$ & $22.20^{\mathrm{b}}$ & $19.20^{\mathrm{b}}$ & $12.12^{\mathrm{b}}$ & $45.25^{b}$ & $68.86^{b}$ & $5.05^{b}$ \\
\hline $\begin{array}{l}\text { White } \\
\text { Chi-so }\end{array}$ & 41.39 & 41.63 & 29.19 & 30.41 & 42.07 & 41.45 \\
\hline P>Chi-sq. & 0.54 & 0.53 & 0.95 & 0.93 & 0.51 & 0.54 \\
\hline
\end{tabular}

${ }^{a}$ The dependent variable in all of the regressions is $\mathrm{V}_{\mathrm{ijt}}$. For the Republican People's Party (CHP) and the People's Democracy Party (HADEP), $\mathrm{V}_{\mathrm{ijt}-4}$ is the Social Democratic Populist Party (SHP) vote share in 1991. In parentheses are the t-statistics in absolute value.

${ }^{\mathrm{b}}$ Coefficient significant at 1 percent level (one-tail test).

${ }^{c}$ Coefficient significant at 5 percent level (one-tail test).

Source: Authors' computations. 
TABLE 4

Coefficient Estimates and Summary Statistics: Robust Regressions

\begin{tabular}{|c|c|c|c|c|c|c|}
\hline \multirow[b]{2}{*}{$\begin{array}{l}\text { Indep. } \\
\text { Variables }\end{array}$} & \multicolumn{6}{|c|}{ Equations (i) ${ }^{a}$} \\
\hline & $\begin{array}{l}\text { True Path } \\
\text { Party }\end{array}$ & $\begin{array}{c}\text { Republican } \\
\text { People's } \\
\text { Party }\end{array}$ & $\begin{array}{l}\text { Motherland } \\
\text { Party }\end{array}$ & $\begin{array}{l}\text { Democratic } \\
\text { Left } \\
\text { Party }\end{array}$ & $\begin{array}{c}\text { Welfare Party } \\
+ \\
\text { Nationalist } \\
\text { Action Party }\end{array}$ & $\begin{array}{l}\text { People's } \\
\text { Democracy } \\
\text { Party }\end{array}$ \\
\hline Constant & $\begin{array}{r}7.35 \\
(0.99)\end{array}$ & $\begin{array}{c}-10.10^{\mathrm{b}} \\
(3.36)\end{array}$ & $\begin{array}{c}-19.03^{b} \\
(3.22)\end{array}$ & $\begin{array}{r}6.35 \\
(1.08)\end{array}$ & $\begin{array}{l}23.14^{\mathrm{b}} \\
(2.79)\end{array}$ & $\begin{array}{r}1.48 \\
(0.93)\end{array}$ \\
\hline $\mathbf{V}_{\mathrm{ijt}-4}$ & $\begin{array}{c}0.56^{\mathrm{b}} \\
(8.69)\end{array}$ & $\begin{array}{c}0.45^{\mathrm{b}} \\
(14.83)\end{array}$ & $\begin{array}{c}1.27^{\mathrm{b}} \\
(17.90)\end{array}$ & $\begin{array}{c}1.38^{\mathrm{b}} \\
(15.37)\end{array}$ & $\begin{array}{c}0.93^{\mathrm{b}} \\
(11.83)\end{array}$ & $\begin{array}{c}0.01 \\
(0.87)\end{array}$ \\
\hline$G_{j t}$ & $\begin{array}{l}0.26^{\mathrm{c}} \\
(1.94)\end{array}$ & $\begin{array}{l}-0.03 \\
(0.55)\end{array}$ & $\begin{array}{c}0.13 \\
(1.20)\end{array}$ & $\begin{array}{r}0.00 \\
(0.04)\end{array}$ & $\begin{array}{l}-0.28^{\mathrm{c}} \\
(1.91)\end{array}$ & $\begin{array}{l}-0.04 \\
(1.34)\end{array}$ \\
\hline$G_{j t-1}$ & $\begin{array}{r}0.08 \\
(1.00)\end{array}$ & $\begin{array}{l}-0.00 \\
(0.02)\end{array}$ & $\begin{array}{l}-0.03 \\
(0.50)\end{array}$ & $\begin{array}{r}0.09 \\
(1.39)\end{array}$ & $\begin{array}{l}-0.09 \\
(1.02)\end{array}$ & $\begin{array}{c}0.01 \\
(0.60)\end{array}$ \\
\hline$S_{j t}$ & $\begin{array}{r}0.03 \\
(0.02)\end{array}$ & $\begin{array}{c}2.68^{\mathrm{b}} \\
(4.07)\end{array}$ & $\begin{array}{r}1.96 \\
(1.59)\end{array}$ & $\begin{array}{l}-2.43^{\mathrm{c}} \\
(1.89)\end{array}$ & $\begin{array}{r}0.01 \\
(0.00)\end{array}$ & $\begin{array}{l}-0.51 \\
(1.48)\end{array}$ \\
\hline $\mathbf{U}_{\mathbf{j t}}$ & $\begin{array}{l}-0.12^{\mathrm{c}} \\
(2.00)\end{array}$ & $\begin{array}{l}-0.07^{\mathrm{b}} \\
(2.79)\end{array}$ & $\begin{array}{l}-0.02 \\
(0.45)\end{array}$ & $\begin{array}{c}0.08^{\mathrm{c}} \\
(1.77)\end{array}$ & $\begin{array}{r}0.06 \\
(0.89)\end{array}$ & $\begin{array}{c}0.03^{\mathrm{b}} \\
(2.29)\end{array}$ \\
\hline $\mathbf{P}_{\mathrm{jt}}$ & $\begin{array}{c}0.75^{\mathrm{c}} \\
(2.25)\end{array}$ & $\begin{array}{l}-0.16 \\
(1.14)\end{array}$ & $\begin{array}{l}-0.36 \\
(1.40)\end{array}$ & $\begin{array}{c}0.44 \\
(1.63)\end{array}$ & $\begin{array}{l}-0.13 \\
(0.36)\end{array}$ & $\begin{array}{r}0.02 \\
0.25)\end{array}$ \\
\hline $\mathbf{N}_{\mathrm{jt}}$ & $\begin{array}{c}-0.27 \\
(1.02)\end{array}$ & $\begin{array}{c}0.05 \\
(0.47)\end{array}$ & $\begin{array}{c}0.55^{\mathrm{b}} \\
(2.53)\end{array}$ & $\begin{array}{l}-0.51^{\mathrm{c}} \\
(2.15)\end{array}$ & $\begin{array}{c}-0.32 \\
(1.11)\end{array}$ & $\begin{array}{c}-0.00 \\
(0.01)\end{array}$ \\
\hline $\mathbf{W}_{\mathrm{jt}}$ & $\begin{array}{r}0.15 \\
(0.93)\end{array}$ & $\begin{array}{r}0.09 \\
(1.32\end{array}$ & $\begin{array}{l}-0.13 \\
(0.96)\end{array}$ & $\begin{array}{l}0.22^{\mathrm{c}} \\
(1.89)^{-}\end{array}$ & $\begin{array}{l}-0.69^{b} \\
(3.18)^{2}\end{array}$ & $\begin{array}{l}0.07^{\mathrm{c}} \\
(1.85)^{-}\end{array}$ \\
\hline $\mathbf{F}$ & $20.7^{\mathrm{b}}$ & $34.4^{\mathrm{b}}$ & $45.2^{\mathrm{b}}$ & $60.5^{\mathrm{b}}$ & $62.5^{\mathrm{b}}$ & 1.5 \\
\hline
\end{tabular}

a The dependent variable in all of the regressions is $\mathrm{V}_{\mathrm{ijt}}$. For the Republican People's Party (CHP) and the People's Democracy Party (HADEP), $\mathrm{V}_{\mathrm{ijt}-4}$ is the Social Democratic Populist Party (SHP) vote share in 1991. In parentheses are the t-statistics in absolute value. Standard errors utilized in obtaining t-values are calculated using the approach described in Street, Carroll and Ruppert (1988).

${ }^{b}$ Coefficient significant at 1 percent level (one-tail test).

${ }^{c}$ Coefficient significant at 5 percent level (one-tail test).

Source: Authors' computations. 


\section{Notes}

1. In 1994 the Turkish economy experienced its severest contraction until that date since 1945 , with a 7.1 percent drop in per capita real GDP. In 1994, two-thirds of the provinces had negative growth rates. In contrast, per capita real GDP grew at a rate of 5.3 percent in 1995, when less than one-fifth of the provinces experienced negative growth rates.

2. Çarkoğlu (1997a) identified wrong parties as incumbents in the 1963, 1964 and 1979 elections. In 1963, the Republican People's Party CHP), and not the Justice Party (AP), was in coalition with the New Turkey Party (YTP) and the Republican Peasant's Nation Party (CKMP). In 1964, the Republican People's Party (CHP) was in power, and not the coalition government involving the Justice Party (AP), the New Turkey Party (YTP) and the Republican Peasant's Nation Party (CKMP). Finally, during the 1979 election, the Republican Reliance Party (CGP) and the Democratic Party (DP) were also in the government besides the Republican People's Party (CHP). Also his vote share figures for 1950, 1954, 1957 and 1977 elections differ from official statistics even though he has picked the correct parties as incumbents for these elections. Genç, Şahin and Bekmez (2005) took the major incumbent party as the winner in 1973, 1977 and 1991 elections, even though it can be verified from their own sources that is not the case. Justice Party (AP) was the major incumbent during the 1973 and 1977 elections and the Motherland Party (ANAP) during the 1991 election. Both parties came in second in the respective elections.

3. The net migration rate at time $t$ is defined as the net migration between $t-5$ and $t$, divided by the population at midpoint between $\mathrm{t}-5$ and $\mathrm{t}$.

4. There were two reasons why we did not consider longer lags of the growth rate. First, even the growth rate lagged one year turned out to have very small and statistically insignificant effects, as will be presented below. Second, while the same two-party coalition was in power during the four years between the two elections considered, the last two years were under a different prime minister than the first two years. We have considered including the level of per capita real GDP in the equation, besides its rate of change. However, what this variable represents, is captured in greater detail, by other variables in the model, such as mean years of schooling, urbanization and net migration rates. Consequently, the addition of per capita real GDP level to the equation did not contribute significantly to its explanatory power.

5. We have also considered number of mosques and clergy per capita, as alternative indicators of religiosity/conservatism. However, we discovered that these variables represent the dispersion of the population rather than its religiosity or conservatism. They attain high values in areas where the population is spread out, as in the Black Sea region, and low values where the population is concentrated in some centers, as in the Central Anatolian region. 
6. Usually each province constitutes a single election district. However, a few populous provinces are divided into two or three electoral districts.

7. The participation rate in the 1995 election was 85.2 percent. This is in between 83.9 and 87.1 percent participation rates observed in 1991 and 1999 elections, respectively. The average for the six parliamentary elections held between 1983 and 2002 is 86.8 .

8. Tuncer (1996) reports that, if the nationwide threshold did not apply, Nationalist Action Party (MHP) would have won 32 of the 550 seats in the parliament, and People's Democracy Party (HADEP), 24 of them.

9. People's Democracy Party (HADEP) also ended up being banned in 2003 by the Constitutional Court on the same grounds as the People's Work Party (HEP), and itself reemerged as another party.

10. Although the Turkish law does not allow two or more parties to enter elections in partnership, it occurs in practice. Usually, the largest of the partner parties enters the election officially and nominates an agreed upon number of other party's candidates as its own. The latter rejoin their own party after the election

11. The Welfare Party (RP) was closed in 1998 by the Constitutional Court for violating the secularism clause of the constitution. The Virtue Party (FP) which replaced the Welfare Party (RP), ended up being banned by the court too in 2001 due to similar violations.

12. We recomposed Karabük and Zonguldak, Yalova and İstanbul, and Kilis and Gaziantep.

13. We partitioned Kars into Kars, Ardahan and Iğdır.

14. 8.34 percent is twice the national vote share of HADEP in the 1995 election. Of the fourteen provinces eliminated, 9 had negative growth rates in 1995. In contrast, only 5 out of the remaining sixty-two provinces had negative growth rates in the same year. The corresponding figures were 9 out of 14 and 41 out of 62 in 1994.

15. The fourteen provinces eliminated from the sample according to this criterion are the following: Adıyaman, Ağrı, Bitlis, Diyarbakır, Hakkari, Mardin, Muş, Siirt, Tunceli, Şanlıurfa, Van, Batman, Şırnak and Iğdır.

16. Due to small number of observations, we did not attempt to build a separate model for the 14 provinces in question.

17. When the residuals of various equations are correlated, the parameters can be estimated more efficiently when the model is treated as a system of "Seemingly Unrelated Regression" (SUR) equations. The latter approach however, has the disadvantage of contaminating the estimation results of all equations when only some of 
them are misspecified. Since the results of the SUR estimation were very similar to those of OLS and Robust regressions given in tables 3 and 4, for brevity, we did not report them separately.

18. Actually Genç, Şahin and Bekmez (2005) list 1954, 1965 and 1991 elections as cases in point. However, as we have mentioned in endnote 2, the major incumbent party did not win the 1991 election. 